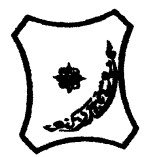

Bayero Journal of Pure and Applied Sciences, 12(2): 111 - 115

Received: March, 2019

Accepted: October, 2019

ISSN $2006-6996$

\title{
INVESTIGATING THE ENVIRONMENTAL POLLUTION CAUSED BY STEEL SLAG IN DANA STEEL ROLLING MILL PLANT, KATSINA
}

\author{
*Yola, I.A. and Sanni, A.A. \\ Department of Mechanical Engineering, Faculty of Engineering, Bayero University, P.M.B 3011 Kano, \\ Nigeria. \\ Corresponding Author: isaaliyuyola@gmail.com or iayola.mec@buk.edu.ng
}

\begin{abstract}
Presence of heavy metals in the soil may contaminate the surrounding environment which causes chronic diseases. The waste steel slag in Dana steel rolling mill Katsina, Nigeria is always dumped within the premises of the company. Therefore, this research examined the level of environmental pollution caused by the deposited steel slag. Minipal 4 version of PW4030 X-Ray Fluorescence Spectrometer (XRF Spectrometer) was used to analyse the chemical composition of sample A (slag), sample B (mill scale), sample C (humus soil) and sample $D$ (humus soil and slag) at Centre for Energy Research and Training, Ahmadu Bello University, Zaria, Kaduna State, Nigeria. Chemical compounds were detected in all the samples with oxides, $\mathrm{Fe}_{2} \mathrm{O}_{3}(11.8 \%-86.13 \%)$ and $\mathrm{SiO}_{2}(4.41 \%$ $57.7 \%)$ dominating. Product moment correlation coefficient was used to compare the effect of Slag (sample A) on Humus soil (sample C). The result obtained has shown that, the calculated value $r=+0.763$ is greater than the table value $r=+0.483$ at $5 \%$ level of significance and 15 d.f. This indicates that, the correlation between the two samples is highly significant. $\mathrm{Fe}_{2} \mathrm{O}_{3}, \mathrm{MnO}$ and $\mathrm{ZnO}$ trace elements in the humus soil were enriched after cultured with slag sample and $\mathrm{P}_{2} \mathrm{O}_{5}, \mathrm{~K}_{2} \mathrm{O}, \mathrm{CaO}$, and $\mathrm{SO}_{3}$ trace elements that are useful for plants growth and development were leached.
\end{abstract}

Keywords: Slag, Mill Scale, Leaching, Pollution, Soil, Environment

\section{INTRODUCTION}

Environmental pollution is defined as the contamination of the physical and biological components of the earth/atmosphere to an extent that normal environmental processes are affected (Iyyanki and Valli 2017). Steel slag is a by- product from the production of iron and steel and is one of the main sources of environmental pollution caused by heavy metals. For several years, industries, lack pollution control regulations especially for metals and hazardous chemicals. Therefore, the accumulation of heavy metals in the environment produces toxic materials which directly or indirectly causes neurological, hepatic, cancer or renal upsets (Javier et al., 2010).

Katsina State is one of the thirty-six (36) states in Nigeria. It was found by Kumayo and was created as a State carved out of old Kaduna state in September, 1989. It is located at latitude $12^{\circ} 59^{\prime} 22 \mathrm{~N}$ and longitude $7^{\circ} 36^{\prime} 2 \mathrm{E}$ and a population of 318,459 people in 2006 census. Katsina occupies 142 square kilometers and its main agricultural product are groundnut, cotton, hides, millets, guinea corn and it also has mills for producing peanut oil and steel. The state is bounded in the east by Kano State, in the west by Sokoto State, in the south by Kaduna State and in the north by the Niger Republic. Katsina Steel Rolling Mill is one of the inland Rolling Mills that were established by the Federal Government of Nigeria to provide steel products, such as iron rods, bars, wires, using billets from the Delta Steel Company, Aladja. The Rolling Mill was privatized in August 27th 2002 and renamed Dana Steel Limited. The Dana steel Rolling commenced production in the year 2006 with the importation of billets as the raw materials. In the year 2008, two (2) Electric Induction Furnaces were used to establish Steel Melting Shop (SMS) in the company. The raw materials (Ferrous Metal Scraps) for the induction furnaces were locally sourced for the production of billets. The Rolling mill mostly depends on material recycling through metal scraps. The Rolling Mill has staff strength of about 260 which comprises of both contract and permanent. The company is equipped with Machine Shop, Engineering Shop, Oxygen Plant, Water recycling Plant, Power Sub-station (3MVA), Backup Generator (9MVA), and Laboratory for testing the chemical compositions of the billets. The company's main products are 
BAJOPAS Volume 12 Number 2, December, 2019

reinforced iron bars and rods. Steel plants have material handling unit such as coke ovens, blast furnaces, other furnaces, casting, rolling, pickling, heat treatment and finishing operations. Water is used in different process such as cooling and washing system. The waste water from the steel slag contains a high concentration of heavy metals due to the accumulation of filtered particles from the filtration process (Lim et al., 2016). A number of chemicals such as Lead, Zinc, Chromates, Phosphates, Chlorides, Phenols and Cyanides may appear in the liquid effluent. Industrial wastes are the wastes products, resulting from the manufacturing processes. These waste products are Liquids, Solids and Gaseous. Many authors have contributed much on the management, disposal, recycling and reuse of these industrial wastes. Major contributions on wastes management are discussed in (Gurcharan and Singh 2003; Rio,2004). The environmental effects like water pollution, land degradation, leaching and health hazards were extensively dealt with in (Gurcharan and Singh, 2003)

In steel Industry, various wastes are been generated and these include Liquid, Gaseous and Solid. The major solid wastes in focus in this research are Steel Slag and mill scale that are generated in Dana Steel Rolling Mill Ltd Katsina.

\section{MATERIALS AND METHODS Materials \\ Materials/Equipment}

MiniPal 4 version PW4030 X-ray Fluorescence Spectrometer, Electronic weighing balance (Mettler AC100), Hydraulic Press (25.000), A binder (PVC dissolve in Toluene)

\section{Samples}

Four solid wastes samples were collected from the dumping site of Dana Steel Ltd. The samples are: Sample A (Steel slag) this is a by - product from the processing of Iron or Scrap steel in an Electric Induction Furnace. They are mainly used as Landfill materials and in road pavement. Sample B ( Mill scale) is a metallic dust that is a by - product of steel. It is normally recycled in steel production. Sample C (Humus soil) can be described as dead organic matter which is in a state of continuous chemical decomposition, transformation and construction. Sample D (mixture of Humus soil and Slag).

\section{Methods}

\section{Sample preparation}

One kilogramme $(1 \mathrm{~kg})$ of each sample was collected and then taken to the Centre for Energy Research and Training, Ahmadu Bello
University, Zaria, Kaduna. The samples were grounded into powder form in Agate Mortal. An electronic weighing balance (Mettler AC100) was used to measure $0.5 \mathrm{~g}$ of each sample and then bonded by a binder (PVC dissolved in Toluene) which were carefully mixed and pressed in a hydraulic press (25.00) to produce four different types of pellets.

\section{Determination of Chemical Composition in the Samples}

MiniPal 4 version of PW4030 X - ray Fluorescence Spectrometer machine was used in this experiment. The machine is designed for the elemental analysis of solids, liquids and powder samples from Sodium to Uranium and provides detection limits at the sub part per million(ppm). It can also measure concentrations of up to $100 \%$ simultaneously. The system is controlled by a PC running the dedicated MiniPal analytical software. The spectrometer has 12-position of removable samples tray plus removable sample holders, which are round. The pellet samples were produced to suit the mounting position and then smoothened for easy passage of the rays. Four pellet samples were loaded at once into the chamber of the Spectrometer machine. A maximum Voltage of $30 \mathrm{kV}$ and a maximum current of $1 \mathrm{~mA}$ were applied to produce the $X-$ rays to excite the samples for a preset time (10 mins). The system was controlled by a PC running the dedicated Mini pal analytical software. The spectrum from the samples were analysed to determine the concentration of the elements in the samples(Abdullahi and Salihi, 2011). The results are shown in table 1.

\section{The Effects of Steel Slag on Humus Soil}

Product moment correlation coefficient $(r)$ is a statistical technique that measures the degree of linear relationship in a bivariate normal distribution where two continuous variables drawn from the same population are compared (Fatima, 2013). Humus Soil was mixed with Steel Slag at mass ratio $3: 1$ and then left for two (2) weeks. Correlation Coefficient Method (Pearson's coefficient of correlation or product moment of correlation coefficient) was used to compare Sample C (Humus soil) and Sample D (Mixture of Humus soil with Slag).

The chemical composition in Oxides of the two samples were converted into elements using Multipliers for Oxide - to - Element as shown in Table 2. Equation 4 was used to compute the value of correlation coefficient ( $r$ ), equations 1,2 and 3 were used to determined the corrected sum of products for $x$ and $y$; sum of squares of $x$ and sum of squares of $y$. 


\section{Quantification of Soil Contamination/Pollution Index (MPI)}

The contamination/pollution index (MPI) is the difference between soil contamination range and soil pollution range. The index value represents the ratio between the heavy metal content measure in soil by chemical analysis and the reference value of contamination from pollution range and those less than $1(<)$ define the contamination range. The two values were divided into interval of values $<0.1$ as very slight contamination, $0.10-0.25$ as slight contamination, $0.26-0.5$ as moderate contamination, $0.51-0.75$ as severe contamination, $0.75-1.00$ as very severe contamination, $1.1-2.0$ as slight pollution, 2.1 - 4.0 as moderate pollution, $4.1-8.0$ as sever pollution, $8.1-16.0$ as very sever pollution and $>16.0$ as excessive pollution (Hong et al. 2014). Contamination/pollution index of metals in soil adopted by Lacatusu (2000) was used in this research to determine the level of environmental pollution caused by dumping slag in the premises of Dana Steel Rolling Mill Katsina. The results are shown in table 4.

\section{RESULTS AND DISCUSSION}

Table 1 shows the chemical compositions of the trace compounds in the four samples. The analysis indicates that at least 17 elements were found in the samples and the samples are dominated with oxides of $\mathrm{Fe}_{2} \mathrm{O}_{3}(11.57 \%-86.13 \%), \mathrm{SiO}_{2}(4.41 \%$ - 41.9\%), $\mathrm{CaO}\left(0.23 \%\right.$ - 15.58\%), $\mathrm{Al}_{2} \mathrm{O}_{3}$ (3 $9.8 \%)$ and $\mathrm{MnO}(0.291 \%-6.69)$. It is observed from the results that some chemical substances in the humus soil were enriched after mixing with slag sample. These substances include $\mathrm{Fe}_{2} \mathrm{O}_{3}($ $11.57 \%$ to $34.51 \%), \mathrm{MnO}(0.29 \%$ to $3.92 \%)$ and $\mathrm{ZnO}(0.499 \%$ to $1.34 \%)$ while the major ones $\mathrm{P}_{2} \mathrm{O}_{5}(11.8 \%$ to $9.4 \%), \mathrm{K}_{2} \mathrm{O}(2.68 \%$ to $1.44 \%), \mathrm{CaO}(10.4 \%$ to $5.23 \%)$ and $\mathrm{SO}_{3}(0.62 \%$ to $0.27 \%$ ) that are useful for plants growth and development were leached.

From Table 2, the computed value of the Product moment correlation coefficient $(r=+0.760)$ is greater than the table value $(r=+0.483)$ at $5 \%$ level of significance and 15 d.f. This indicates a strong positive correlation between the humus soil(sample C) and steel slag (sample D). As the calculated value +0.76 is greater than the table value +0.483 , this indicates that, the correlation between the two samples is highly significant.

The results in Table 3 show the effects of Slag on Humus soil. It is observed that both major and minor elements were either leached or enriched. The leached elements may get to the water-table and contaminate the bore-holes or wells that are around the places.

The results in Table 4 show that Chromium has excessively contaminated the soil while $\mathrm{V}, \mathrm{M}, \mathrm{Ni}$, $\mathrm{Cu}$ and $\mathrm{Ba}$ have severely contaminated the soil. $\mathrm{Zn}$ and Fe have moderately contaminated the soil and lastly Ti has slightly contaminated the soil.

Table 1: Chemical Compositions in the samples

\begin{tabular}{|c|c|c|c|c|c|}
\hline $\mathrm{S} / \mathrm{NO}$ & $\begin{array}{l}\text { Chemical Composition } \\
\text { (Concentration in \%) }\end{array}$ & $\begin{array}{l}\text { Sample A } \\
\text { (Slag) }\end{array}$ & $\begin{array}{l}\text { Sample B } \\
\text { (Mill scale) }\end{array}$ & $\begin{array}{l}\text { Sample C } \\
\text { (Humus soil) }\end{array}$ & $\begin{array}{l}\text { Sample D } \\
\text { (Humus soil \& Slag) }\end{array}$ \\
\hline 1 & $\mathrm{Al}_{2} \mathrm{O}_{3}$ & 4.0 & 3 & 11.8 & 9.4 \\
\hline 2 & $\mathrm{SiO}_{2}$ & 41.9 & 4.41 & 57.7 & 38.2 \\
\hline 3 & $\mathrm{P}_{2} \mathrm{O}_{5}$ & ND & 0.16 & 1.8 & 1.3 \\
\hline 4 & $\mathrm{SO}_{3}$ & 0.87 & ND & 0.62 & 0.27 \\
\hline 5 & $C L$ & 0.11 & 0.052 & 0.16 & 0.10 \\
\hline 6 & $\mathrm{~K}_{2} \mathrm{O}$ & 0.938 & 0.02 & 2.68 & 1.44 \\
\hline 7 & $\mathrm{CaO}$ & 15.58 & 0.23 & 10.4 & 5.23 \\
\hline 8 & $\mathrm{TiO}_{2}$ & 2.71 & ND & 1.44 & 1.71 \\
\hline 9 & $\mathrm{~V}_{2} \mathrm{O}_{5}$ & 0.078 & 0.04 & 0.07 & 0.069 \\
\hline 10 & $\mathrm{Cr}_{2} \mathrm{O}_{3}$ & 1.05 & 0.263 & 0.057 & 0.761 \\
\hline 11 & $\mathrm{MnO}$ & 6.69 & 0.759 & 0.291 & 3.92 \\
\hline 12 & $\mathrm{Fe}_{2} \mathrm{O}_{3}$ & 22.97 & 86.13 & 11.57 & 34.51 \\
\hline 13 & $\mathrm{NiO}$ & 0.955 & 0.19 & 0.569 & 0.395 \\
\hline 14 & $\mathrm{CuO}$ & 0.089 & 0.18 & 0.059 & 0.058 \\
\hline 15 & $\mathrm{ZnO}$ & 1.40 & 0.02 & 0.499 & 1.34 \\
\hline 16 & $\mathrm{Ga}_{2} \mathrm{O}_{3}$ & 0.05 & 0.02 & 0.03 & ND \\
\hline 17 & $\mathrm{BaO}$ & 0.60 & ND & 0.33 & 0.29 \\
\hline 18 & $\mathrm{Br}$ & ND & 1.8 & ND & ND \\
\hline 19 & $\mathrm{MoO}_{3}$ & ND & 0.22 & ND & ND \\
\hline 20 & $\mathrm{CdO}$ & ND & 2.0 & ND & ND \\
\hline 21 & $\mathrm{Re}_{2} \mathrm{O}_{7}$ & ND & 0.10 & ND & ND \\
\hline 22 & $\mathrm{O}_{5} \mathrm{O}_{4}$ & ND & 0.14 & ND & $\mathrm{ND}$ \\
\hline
\end{tabular}


BAJOPAS Volume 12 Number 2, December, 2019

Table 2 : Statistical Analysis (Correlation Coefficient [r])

\begin{tabular}{llllll}
\hline Chemical & $\begin{array}{c}\text { Sample } \mathrm{C} \\
\text { Elements }\end{array}$ & $\begin{array}{c}\text { Sample } \mathrm{D} \\
(\mathrm{Y})\end{array}$ & $\mathrm{XY}$ & $\mathrm{X}^{2}$ & $\mathrm{Y}^{2}$ \\
\hline $\mathrm{AL}$ & 6.24 & 4.97 & 31.0128 & 38.9376 & 24.7009 \\
$\mathrm{Si}$ & 26.95 & 18.31 & 493.4545 & 726.3025 & 335.2561 \\
$\mathrm{P}$ & 0.78 & 0.57 & 0.4446 & 0.6084 & 0.3249 \\
$\mathrm{~S}$ & 0.25 & 0.11 & 0.0275 & 0.0625 & 0.0121 \\
$\mathrm{CL}$ & 0.16 & 0.1 & 0.016 & 0.0256 & 0.01 \\
$\mathrm{~K}$ & 2.22 & 1.2 & 2.664 & 4.9284 & 1.44 \\
$\mathrm{Ca}$ & 7.43 & 3.74 & 27.7882 & 55.2049 & 13.9876 \\
$\mathrm{Ti}$ & 0.86 & 1.02 & 0.8772 & 0.7396 & 1.0404 \\
$\mathrm{~V}$ & 0.04 & 0.04 & 0.0016 & 0.0016 & 0.0016 \\
$\mathrm{Cr}$ & 0.03 & 0.52 & 0.0156 & 0.0009 & 0.2704 \\
$\mathrm{Mn}$ & 0.23 & 3.03 & 0.6969 & 0.0529 & 9.1809 \\
$\mathrm{Fe}$ & 8.09 & 24.12 & 195.138 & 65.441 & 581.774 \\
$\mathrm{Ni}$ & 0.45 & 0.31 & 0.1395 & 0.2025 & 0.0961 \\
$\mathrm{NCu}$ & 0.05 & 0.05 & 0.0025 & 0.0025 & 0.0025 \\
$\mathrm{Zn}$ & 0.4 & 1.08 & 0.432 & 0.16 & 1.1664 \\
$\mathrm{Ga}$ & 0.02 & 0 & 0 & 0.0004 & 0 \\
$\mathrm{Ba}$ & 0.3 & 0.26 & 0.078 & 0.09 & 0.0676 \\
$\mathrm{Total}$ & 54.5 & 59.43 & 752.7817 & 892.7684 & 969.3319 \\
\hline $\mathrm{CALCULATH}$ & $\mathrm{NS}$ & & & & \\
\hline
\end{tabular}

CALCULATIONS:

n =17, $\quad \Sigma y=59.43 ; \quad \Sigma x=54.5 ; \quad \Sigma x y=752.7817 ; \quad \Sigma x^{2}=892.7684 ; \Sigma y^{2}=969.3319$

$\mathrm{SP}_{x y}=$ is the corrected sum of products for $\mathrm{x}$ and $\mathrm{y}$ also referred to as Covariance:

$S P_{x y}=\sum x y-\frac{(\Sigma x)(\Sigma y)}{n}=562.2561$

SSX is the sum of squares for $X$, which is given as :

$S S_{x}=\Sigma x^{2}-\frac{(\Sigma x)^{2}}{n}=718.0478$

SSy is the sum of squares of $Y$, which is given as :

$S S_{Y}=\Sigma y^{2}-\frac{(\Sigma y)^{2}}{n}=761.5716$

Product correlation coefficient $=r=\frac{S P_{k y}}{\sqrt{\left(S S_{x}\right)\left(S S_{y}\right)}}=0.76$

Table 3: Effects of Slag on the Humus soil

\begin{tabular}{llll}
\hline Chemical Composition & $\begin{array}{l}\text { Sample C } \\
\text { concentration in } \\
\%\end{array}$ & $\begin{array}{l}\text { Sample D concentration } \\
\text { in } \%\end{array}$ & $\begin{array}{l}\text { Inferences } \\
\mathrm{Al}_{2} \mathrm{O}_{3}\end{array}$ \\
$\mathrm{SiO}_{2}$ & 11.8 & 9.4 & Leached \\
$\mathrm{P}_{2} \mathrm{O}_{5}$ & 57.7 & 39.2 & Leached \\
$\mathrm{SO}_{3}$ & 1.8 & 1.3 & Leached \\
$\mathrm{Cl}$ & 0.62 & 0.27 & Leached \\
$\mathrm{K}_{2} \mathrm{O}$ & 0.16 & 0.10 & Leached \\
$\mathrm{CaO}$ & 2.68 & 1.44 & Leached \\
$\mathrm{TiO}_{2}$ & 10.4 & 5.43 & Leached \\
$\mathrm{V}_{2} \mathrm{O}_{5}$ & 1.44 & 1.71 & Enriched \\
$\mathrm{Cr}_{2} \mathrm{O}_{3}$ & 0.070 & 0.069 & Leached \\
$\mathrm{MnO}$ & 0.047 & 0.761 & Enriched \\
$\mathrm{Fe}_{2} \mathrm{O}_{3}$ & 0.291 & 3.92 & Enriched \\
$\mathrm{NiO}$ & 11.57 & 34.51 & Enriched \\
$\mathrm{CuO}$ & 0.569 & 0.395 & Leached \\
$\mathrm{ZnO}$ & 0.059 & 0.058 & Leached \\
$\mathrm{Ga} \mathrm{O}_{3}$ & 0.499 & 1.34 & Enriched \\
& 0.03 & 0.00 & Leached \\
$\mathrm{BaO}$ & & & completely \\
& 0.33 & 0.29 & Leached \\
\hline
\end{tabular}


BAJOPAS Volume 12 Number 2, December, 2019

Table 4 Contamination/Pollution index for heavy metals in the soil

\begin{tabular}{|c|c|c|c|c|c|}
\hline $\begin{array}{l}\text { Chemical } \\
\text { Composition }\end{array}$ & $\begin{array}{l}\text { Humus Soil mixed } \\
\text { with Slag } \\
\text { Concentration in } \\
\text { percentages }\end{array}$ & $\begin{array}{l}\text { Humus Soil } \\
\text { Concentration } \\
\text { in percentages }\end{array}$ & $\begin{array}{l}\text { Concentration/ } \\
\text { Pollution index } \\
\text { [MPI] }\end{array}$ & $\begin{array}{l}\text { Class interval } \\
\text { according to } \\
\text { Lactusu } 2000\end{array}$ & \\
\hline $\mathrm{Ti}$ & 1.02 & 0.86 & 1.19 & $1-2.0$ & SP \\
\hline V & 0.04 & 0.04 & 1 & $0.76-1$ & VSC \\
\hline $\mathrm{Cr}$ & 0.52 & 0.03 & 17.3 & $>16$ & $\begin{array}{l}\text { Excessive } \\
\text { contamination }\end{array}$ \\
\hline$M$ & 3.03 & 0.23 & 13.17 & $8.1-16$ & VSC \\
\hline $\mathrm{Fe}$ & 24.12 & 8.09 & 2.98 & $2.1-4.0$ & MP \\
\hline $\mathrm{Ni}$ & 0.31 & 0.45 & 0.69 & $0.5-0.75$ & Severe contamination \\
\hline $\mathrm{Cu}$ & 0.05 & 0.05 & 1 & $0.76-1$ & VSC \\
\hline $\mathrm{Zn}$ & 1.08 & 0.4 & 2,7 & $2.1-4$ & Moderate pollution \\
\hline $\mathrm{Ga}$ & 0 & 0.02 & 0 & & \\
\hline $\mathrm{Ba}$ & 0.26 & 0.3 & 0.86 & $0.76-1$ & VSC \\
\hline
\end{tabular}

Key: SP = Slight pollution, VS = Very severe Contamination, MP = Moderate pollution

\section{CONCLUSION}

$\mathrm{SiO}_{2}$ and $\mathrm{Fe}_{2} \mathrm{O}_{3}$ are the substances that have higher percentages in the four samples while the remaining ranged between $0.02 \%$ - $15.5 \%$.

Major and minor elements were affected by decreasing or enriching the quantities of the chemical compositions of the slag on humus soil The elements that were leached can contaminate bore-holes and wells that are near the dumping site of the wastes, which may cause health problems.

Some percentages of useful elements to plants growth and development were leached which may have an effect on both plants and animals.

The results obtained confirmed that the solid wastes contained non-metallic by-products which consist mainly oxides of silica, Alumina, Lime, Magnesia.

\section{REFERENCES}

Abdullahi, U. and Salihi, A.(2011), "Characterization and Potential Application of Kano Cattle Horns". 6(1 \& 2) : 32- 40.

Fatima, B.M, (2013). "Introduction to Biostatistics", $3^{\text {rd }}$ Edition, Ahmadu Bello University Press, Zaria, Kaduna, Nigera.

Gurcharan and Singh,J, (2003). "Water Supply and Sanitary Engineering". $6^{\text {th }}$ edition, New Chand Jain, Delhi, pp $370-386$.

Hong et al, (2014). Environmental Burden of heavy Metal contamination levels in soil from sewage irrigation Area of Geriyo Catment, Nigeria. Journal of civil and Environmental Research. 6(10)

Iyyanki, V. M. and Valli M.(2017). Environmental Management.

Javieren, G.G.,Virgililio, C., Loreno, R.V., Elena, C.F., Rafael, G.M. and Laura T. (2010). Influence of accumulation of heaps of
The results also revealed that, the soil contained substantial amount of heavy metals in the dumping site.

The metal contamination /pollution index assessment revealed that the soil mostly belongs to the class of very severe contamination to moderate pollution

\section{RECOMMENDATIONS}

Slag generated from Electric Induction Furnace needs to be disposed off without heaping them around the factory premises. Some iron content from the slag can be recovered through the use of magnetic separation. This will help in reducing the environmental and health implications of these solid wastes. The mill scale waste is primarily iron waste and has a market value. Mill scale is often recycled by the steel plants and those that cannot be recycled by steel plants can be used by Portland cement plants as an iron source.

steel slag on the environment: Determination of heavy metals content in soils. An. Acad. Bras. CienC. Vol.82 no.2

Lacatusu, R. (2000). "Appraising Levels of Soil Contamination and Pollution with Heavy Metals in Soil". European Soil Research Report, No 4 office of official publication of the European Communities, L uxembourg, pp.393-402

Lim, J.W., Chew,L.H., Choong, T.S.Y., Tezara, C., Yazdi, M. H.(2016). Utilizing Steel Slag in Environmental application-An overview. International Conference on Chemical Engineering and Bioprocess IOP Conf. Series: Earth and Environmental Science. 36: $1-7$.

Rao, V.P. (2004). "Textbook of Environmental Engineering", Asoke K. Ghosh , prentice Hall of India private Ltd; New Delhi. pp 155. 